\title{
Temporal Variations of Water Chemistry in the Wet Season in a Typical Urban Karst Groundwater System in Southwest China
}

\author{
Min Xiao ${ }^{1, *}$, Zenglei Han ${ }^{1}$, Sen $\mathrm{Xu}^{2} \mathbb{D}$ and Zhongliang Wang ${ }^{1}$ \\ 1 Tianjin Key Laboratory of Water Resources and environment, Tianjin Normal University, Tianjin 300387, \\ China; 1810080004@stu.tjnu.edu.cn (Z.H.); wangzhongliang@vip.skleg.cn (Z.W.) \\ 2 Institute of Surface-Earth System Science, Tianjin University, Tianjin 300072, China; xusen@tju.edu.cn \\ * Correspondence: xiaomin@tjnu.edu.cn
}

Received: 23 February 2020; Accepted: 1 April 2020; Published: 7 April 2020

\begin{abstract}
It is important to investigate temporal variations of water chemistry for the purpose of improving water quality in karst groundwater systems. Groundwater samples were collected daily under various land uses of Guiyang. Major ions and stable carbon isotope composition of dissolved inorganic carbon $\left(\delta^{13} \mathrm{C}_{\mathrm{DIC}}\right)$ were analyzed to understand the biogeochemical processes. The water chemistry was dominated by $\mathrm{Ca}^{2+}, \mathrm{Mg}^{2+}, \mathrm{HCO}_{3}{ }^{-}$, and $\mathrm{SO}_{4}{ }^{2-}$, which mainly derived from the dissolution of carbonate rocks (limestone and dolomite) and oxidation of sulfide. The groundwater was defined as of the $\mathrm{HCO}_{3}-\mathrm{Ca} \mathrm{Mg}$ and $\mathrm{HCO}_{3} \cdot \mathrm{SO}_{4}-\mathrm{Ca} \cdot \mathrm{Mg}$ type, according to its hydrochemical characteristics. Results suggested that hydrochemical concentrations changed quickly, in response to rainfall events. The fast response revealed that karst groundwater was easily impacted by rainfall and anthropogenic inputs according to temporal variation of water chemistry. The distribution of DIC (dissolved inorganic carbon) and $\delta^{13} \mathrm{C}_{\mathrm{DIC}}$ showed that DIC is mainly sourced from soil $\mathrm{CO}_{2}(\mathrm{~g})$ influx and carbonate dissolution. $\delta^{13} \mathrm{C}_{\mathrm{DIC}}$ and major ions ratios suggested that carbonate minerals were dissolved by $\mathrm{H}_{2} \mathrm{SO}_{4}$ at groundwater in wooded area, contributing an important source for DIC due to the slight enrichment of heavy $\delta^{13} C_{\text {DIC }}$. More negative $\delta^{13} C_{\text {DIC }}$ values were observed after rainfall reflected the fact that soil $\mathrm{CO}_{2}(\mathrm{~g})$ and organic carbon oxidation influxes accounted for a large share during DIC formation. Various $\delta^{13} \mathrm{C}_{\mathrm{DIC}}$ and hydrochemical patterns were observed under various land use and human activity conditions. Meanwhile, relative high nitrate loads were found in groundwater after rainfall, suggesting high anthropogenic inputs following rainwater as having side effects on water quality. This study suggests that water chemistry and isotopic proof provide a better understanding of water quality and carbon dynamics responding to rainfall events in the karst groundwater systems.
\end{abstract}

Keywords: water chemistry; dissolved inorganic carbon; carbon isotope; carbonate rock weathering; groundwater

\section{Introduction}

Karst aquifers are important for supplying a large amount of fresh water for the whole world [1]. The karst landscape covers nearly 15\% of the Earth's land area, providing drinking water for 1/4 of the world's population [2]. Groundwater is important for drinking and irrigation in the karst area, therefore, understanding the biogeochemical processes in karst areas is extremely significant [3-6]. Groundwater is an important part in the karstic ecosystem, but it is particularly sensitive to environmental changes and human activities $[5,7,8]$. With the acceleration of urbanization and industrialization, the eco-environment in karst areas is susceptible to being affected $[9,10]$. 
Stable carbon isotope $\left({ }^{13} \mathrm{C}\right)$ and water chemistry parameters, can be acted as important tools to understand the biogeochemical processes in groundwater systems [5,6]. Karstic water is one of the most important groundwater resources supplying drinking water for more than 100 million people in Southwest China $[8,11]$. The aquifers provide a natural storage and movement for groundwater. In the studied region, the soil layers are thin and lack enough filtration for contamination. With the development of karst folding, a fault, and a fracture under the complex hydrogeological conditions, the contaminants on the earth's surface could seep into aquifers directly or indirectly [9]. The special structure would result in changing the chemical composition drastically and leading to the deterioration of groundwater quality. Groundwater is a "hidden reservoir" of pollutants, and it is difficult to monitor. Springs are natural outcrops of groundwater and main drain $[6,12]$. The contaminants in aquifers will eventually show up in springs. Therefore, springs naturally become the monitoring medium for contaminants and the hydrogeochemical processes of groundwater in karst aquifers can be fully understood.

Hydrochemical composition is the basis for probing sources, runoff, and the eco-environment, and is important content for assessing groundwater resources [13]. It is of much guiding significance for utilizing and managing groundwater resources in the drainage basin, and the related protection of the eco-environment and construction $[14,15]$. The $\delta^{13} \mathrm{C}$ values of different carbon sources are differentiated obviously, and the environmental changes of groundwater would influence biogeochemical cycles of carbon and isotopic composition [4-6]. The average $\delta^{13} \mathrm{C}$ being added to the $\mathrm{SO}_{4}{ }^{2-}$-rich groundwater is $-9.4 \%$, while the average $\delta^{13} \mathrm{C}$ being added is $-11.6 \%$ for the $\mathrm{HCO}_{3}$-rich groundwater, due to dedolomitization and soil $\mathrm{CO}_{2}(\mathrm{~g})$ dissolution in groundwater [16]. The $\delta^{13} \mathrm{C}$ not only discern the sources of DIC in groundwater, but also identify the sources of contamination in groundwater as well as the biogeochemical processes, which influence the migration and fate of contaminants $[5,10]$. It was pointed out that the heaviest $\delta^{13} \mathrm{C}$ values of $-8.5 \%$ in an aquifer containing gypsum, lowest $\delta^{13} \mathrm{C}$ values of $-14.4 \%$ in an aquifer contaminated by organic pollutants [5]. The hydrochemical and isotopic detection of spring provides the method to obtain the information on recharge of groundwater, formation lithology, water-rock interaction, and land-use type that greatly impact the quality of ground water $[5,6,11]$.

In order to clarify the regional recharge source for groundwater and hydraulic connections in a karst aquifer, we provide reasonable and effective suggestions for management and utilization of groundwater resources. The main objectives of this study are: (1) to analyze the hydrochemical characteristics responding to rainfall in this area, determine the subsequent reactions on the carbonate evolution, and further probe the hydrogeochemical evolutionary process in groundwater, thereby comprehensively understanding the impact of human activities on karst aquifer; (2) to understand the DIC sources in fresh groundwater and document the spatial and temporal characteristics for chemical components and stable carbon isotopes in Guiyang, Southwest China.

\section{Materials and Methods}

\subsection{Study Area}

The city of Guiyang is situated at $106^{\circ} 07^{\prime} \mathrm{E}-107^{\circ} 17^{\prime} \mathrm{E}$ longitude and $26^{\circ} 11^{\prime} \mathrm{N}-26^{\circ} 55^{\prime} \mathrm{N}$ latitude, in the centre of Guizhou Province, Southwest China. It covers an area of $2960 \mathrm{~km}^{2}$, with an average elevation of around $1400 \mathrm{~m}$, characteristic of plateau hilly landforms [5,10]. Guiyang is located close to the boundary, separating the Changjiang River and Pearl River basins, occupying a wide karstic valley basin in the central part of Guizhou Province. Permian and Triassic carbonate rocks are widely distributed in the region; this kind of geology took an area over $70 \%$, the lithology is mainly dolomite and limestone, and part of it contains organic-and sulfide-rich limestone [11]. Groundwater is rich in the terrain with karst development. The Guiyang basin is restricted and controlled by the combination of the topographic features of folding, a fault, and fracture structure planes, forming a karst underground water network model and groundwater accumulation area. Woodland, arable land, and urban land are 
the main land-use patterns within the sampling region. The climate in Guiyang city is subtropical with an average temperature of $16^{\circ} \mathrm{C}$ and annual precipitation of about $1200 \mathrm{~mm}$. A monsoonal climate often results in high precipitation during summer and much less during winter at the studied region. Rainfall is concentrated from May to August and the dominant recharge to ground water is dependent on rain water $[8,9]$.

\subsection{Sampling and Analytical Method}

Ground water samples were collected in August, 2011, corresponding to the high-flow seasons. Four sampling sites were selected situated at ZZ (Zhen Zhu, name of site) where it is newly urbanized with some cropland. NN (Nai Niu, name of site) is partially forested with some residents in the immediate surroundings, who cultivate crops and raise cows. ZZ and NN are gravity springs, with a mean discharge of $41.2 \mathrm{~L} / \mathrm{s}$ and $1 \mathrm{~L} / \mathrm{s}$ [11], respectively. DJ (Dong Jiao, name of site) is artesian spring having a discharge of $1571 \mathrm{~L} / \mathrm{s}$ and located in a large area of woodland at the mountain zone [11]. $\mathrm{DH}$ (Di Hua, name of site) is a well with a discharge of $6.3 \mathrm{~L} / \mathrm{s}$ and sits in the centre of the city (Figure 1). The Nanming River is the trunk stream, and the water flow direction is from southwest to northeast (Figure 1). Groundwater samples were collected every day in one month, and in total, over one hundred samples were collected. Meanwhile, the daily data of rainfall were collected synchronously during the sampling period through website of local meteorological bureau (http://gz.cma.gov.cn/). Temperature, electrical conductivity, and $\mathrm{pH}$ were measured in situ. Alkalinity was measured by titration with $0.02 \mathrm{M} \mathrm{HCl}$ within $12 \mathrm{~h}$. Major cations $\left(\mathrm{Mg}^{2+}, \mathrm{Ca}^{2+}, \mathrm{Na}^{+}\right.$, and $\left.\mathrm{K}^{+}\right)$were analyzed by atomic absorption spectrometry once samples were filtered and acidified, and anions $\left(\mathrm{SO}_{4}{ }^{2-}, \mathrm{NO}_{3}{ }^{-}\right.$, and $\mathrm{Cl}^{-}$) were analyzed by high-performance liquid chromatography.

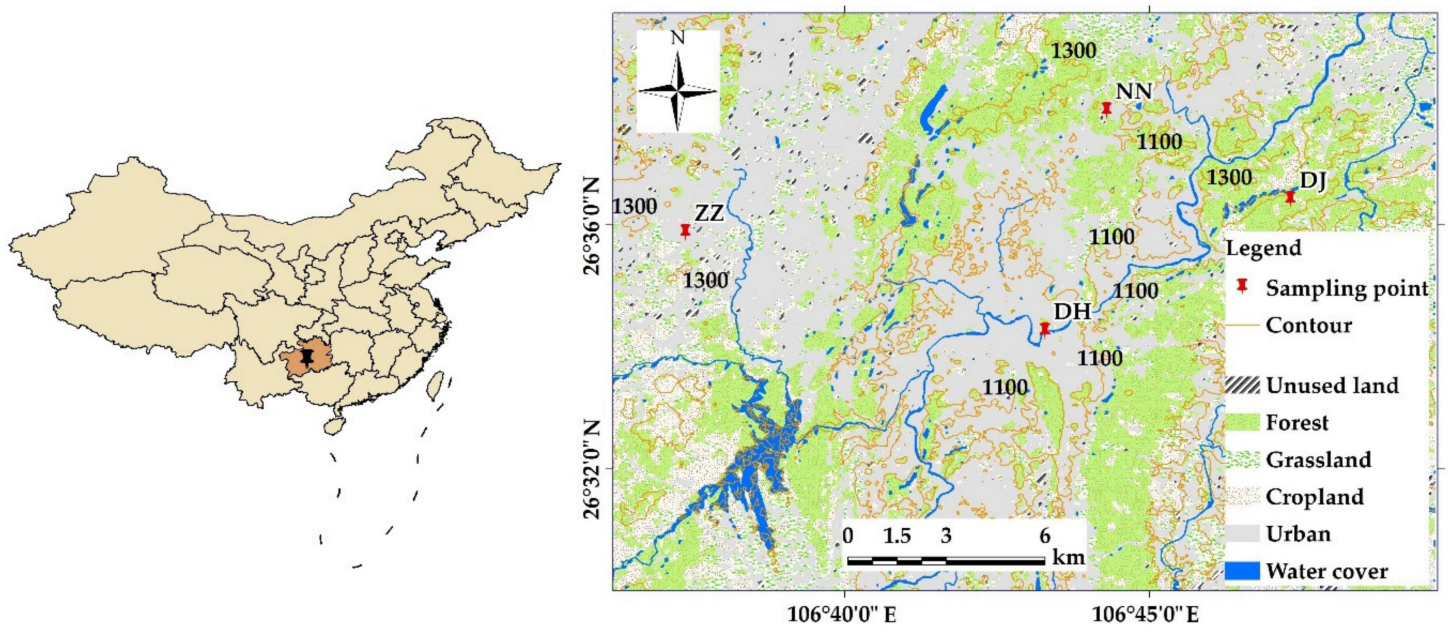

Figure 1. Sampling sites of groundwater and land utilization of Guiyang City, SW China.

For the determination of $\delta^{13} C_{\text {DIC }}$, samples were filtered through $0.45 \mu \mathrm{m}$ cellulose acetate filter paper in order to avoid the potential influence of carbonate mineral particles. Some water samples were selected for isotopic analysis due to limitations of cost and time in this study. Using the method of Li et al. (2005) [5], $10 \mathrm{~mL}$ water sample was injected into glass bottles that were prefilled with $85 \%$ phosphoric acid and a magnetic stir bar by syringe. Then $\mathrm{CO}_{2}$ was extracted and purified into a vacuum line. Finally, the purified $\mathrm{CO}_{2}$ was transferred cryogenically into a tube welded for isotopic measurements. Carbon isotope ratios were determined on a Finnigan MAT 252 mass spectrometer (Thermo Finnigan GmbH Inc., Bremen, Germany) and reported in the $\delta$ notation relative to Vienna Pee Dee Belemnite (PDB) in per mill, (see Equation (1)):

$$
\delta_{\text {sample }}(\% o)=\left(\left(R_{\text {sample }} \div R_{V P D B}\right)-1\right) \times 1000
$$


where $R$ is the ${ }^{13} \mathrm{C} /{ }^{12} \mathrm{C}$ atomic ratio. Routine $\delta^{13} \mathrm{C}_{\mathrm{DIC}}$ has an overall precision of $0.1 \%$. $10 \%$ of duplicate samples were measured, and the results showed that the differences were lower than the measurement accuracy.

\section{Results}

\subsection{Hydrochemical Characteristics of Groundwater}

The $\mathrm{pH}$ values of groundwater ranged from 6.0-8.0, which reflected the influence of the soil water with high $\mathrm{CO}_{2}$ concentrations. Under the observed $\mathrm{pH}$ conditions, bicarbonate $\left(\mathrm{HCO}_{3}{ }^{-}\right)$was the dominant DIC species $[9,17,18]$ and the ion abundance was related to the dissolution equilibrium of the carbonate minerals. The average TDS (Total dissolved solids) values were $564 \mathrm{mg} \cdot \mathrm{L}^{-1}$ for groundwater in summer [11]. The daily rainfall ranged from $0-89.6 \mathrm{~mm}$, and averaged at $11.99 \mathrm{~mm}$.

The major ion concentrations of samples are listed in Table S1. The charge balance errors between cations and anions in groundwater were equivalent to or less than $5 \%$. It was obvious that $\mathrm{Ca}^{2+}$ and $\mathrm{Mg}^{2+}$ were the dominant cations, and $\mathrm{HCO}_{3}{ }^{-}$and $\mathrm{SO}_{4}{ }^{2-}$ were the dominant anions (Figure 2), which accounted for $96 \%$ and $92.5 \%$ of cation and anion in milliequivalents (mEq), respectively. As illustrated in Figure 2, hydrochemical types of spring water in Guiyang were predominantly $\mathrm{HCO}_{3}-\mathrm{Ca} \cdot \mathrm{Mg}$ and $\mathrm{HCO}_{3} \cdot \mathrm{SO}_{4}-\mathrm{Ca} \cdot \mathrm{Mg}$. The chemical compositions of groundwater were characterized by a anion sequence of $\mathrm{HCO}_{3}{ }^{-}>\mathrm{SO}_{4}{ }^{2-}>\mathrm{NO}_{3}{ }^{-}+\mathrm{Cl}^{-}$, accounting for $74 \%, 18 \%$, and $7 \%$ of the total anions, respectively. The $\mathrm{NO}_{3}{ }^{-}$level of groundwater at the residential district was higher than that of woodland. $\mathrm{NO}_{3}{ }^{-}$was the most concentrated at $\mathrm{DH}$ with the proportion of $5 \%$ in total anions, with the absolute average amounts of $32.41 \mathrm{mg} \cdot \mathrm{L}^{-1}$. Similar to $\mathrm{NO}_{3}{ }^{-}, \mathrm{SO}_{4}{ }^{2-}$ was the highest at $\mathrm{DH}$, with a range from $114.4-188.9 \mathrm{mg} \cdot \mathrm{L}^{-1}$ (averaging $144.7 \pm 16.6 \mathrm{mg} \cdot \mathrm{L}^{-1}$ ). The $\mathrm{SO}_{4}{ }^{2-}$ concentrations averaged at $25.9 \pm 2.4,33.35 \pm 0.27$, and $31.51 \pm 4.1 \mathrm{mg} \cdot \mathrm{L}^{-1}$ at $\mathrm{ZZ}, \mathrm{NN}$, and $\mathrm{DJ}$, with ranges of 20.45-35.42, 20.73-50.13, and 23.86-38.01 $\mathrm{mg} \cdot \mathrm{L}^{-1}$, respectively.

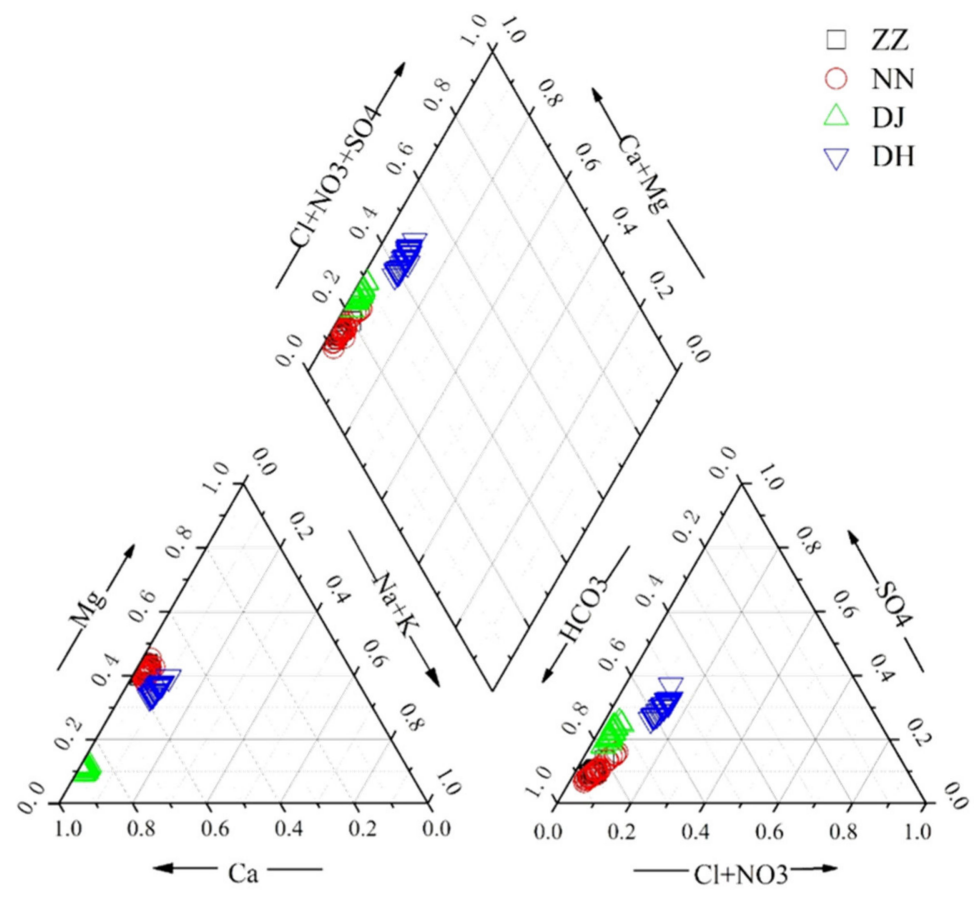

Figure 2. Trilinear diagram of hydrochemical composition in ground water samples in study area.

$\mathrm{HCO}_{3}{ }^{-}$was relative high at $\mathrm{NN}$ and $\mathrm{DH}$, with averages of $66.52 \pm 1.97$ and $65.80 \pm 0.92 \mathrm{mg} \mathrm{C} \cdot \mathrm{L}^{-1}$, whereas $55.69 \pm 0.73$ and $26.96 \pm 1.01 \mathrm{mg} \mathrm{C} \cdot \mathrm{L}^{-1}$ were found at $\mathrm{ZZ}$ and DJ, respectively. $\mathrm{Cl}^{-}$occupied the highest and lowest levels at DH and DJ, averaging $29.02 \pm 2.47$ and $1.60 \pm 0.35 \mathrm{mg} \cdot \mathrm{L}^{-1}$, respectively. 
$\mathrm{Cl}^{-}$at $\mathrm{ZZ}$ and $\mathrm{NN}$ fell into the ranges of 3.5-5.8 and 3.47-5.64 $\mathrm{mg} \cdot \mathrm{L}^{-1}$, averaging $4.24 \pm 0.46$ and $4.42 \pm 0.58 \mathrm{mg} \cdot \mathrm{L}^{-1}$. For cations, the average concentrations of $\mathrm{Ca}^{2+}(64 \%)$ and $\mathrm{Mg}^{2+}(32 \%)$ were much higher than those of $\mathrm{K}^{+}$and $\mathrm{Na}^{+}(4 \%)$. As the most abundant cation species, $\mathrm{Ca}^{2+}$ and $\mathrm{Mg}^{2+}$ at $\mathrm{DH}$ averaged $108.28 \pm 10.06$ and $41.95 \pm 1.66 \mathrm{mg} \cdot \mathrm{L}^{-1}$, respectively. Followed by NN, $\mathrm{Ca}^{2+}$, and $\mathrm{Mg}^{2+}$ have mean value of $70.58 \pm 5.19$ and $31.43 \pm 0.68 \mathrm{mg} \cdot \mathrm{L}^{-1}$, respectively. $\mathrm{Ca}^{2+}$ and $\mathrm{Mg}^{2+}$ have a range of $56.83-66.33 \mathrm{mg} \cdot \mathrm{L}^{-1}$ and $25.88-29.28 \mathrm{mg} \cdot \mathrm{L}^{-1}$ at $\mathrm{ZZ}$, with average values of $61.57 \pm 2.34 \mathrm{mg} \cdot \mathrm{L}^{-1}$ and $27.66 \pm 0.63 \mathrm{mg} \cdot \mathrm{L}^{-1}$, respectively. Levels of $47.18-56.35 \mathrm{mg} \cdot \mathrm{L}^{-1}$ for $\mathrm{Ca}^{2+}$ and $3.38-4.38 \mathrm{mg} \cdot \mathrm{L}^{-1}$ for $\mathrm{Mg}^{2+}$ were observed, with averages of $52.86 \pm 2.34$ and $3.83 \pm 0.29 \mathrm{mg} \cdot \mathrm{L}^{-1}$ at DJ, respectively. $\mathrm{Na}^{+}$ and $\mathrm{K}^{+}$were the lower cationic species in the total cations and the gross of $\mathrm{Na}^{+}+\mathrm{K}^{+}$ranged from 18.86-22.43 mg. $\mathrm{L}^{-1}, 3.61-9.99 \mathrm{mg} \cdot \mathrm{L}^{-1}, 2.71-5.85 \mathrm{mg} \cdot \mathrm{L}^{-1}$, and $1.4-2.13 \mathrm{mg} \cdot \mathrm{L}^{-1}$ at $\mathrm{DH}, \mathrm{NN}, \mathrm{ZZ}$, and DJ, with mean values of $20.84 \pm 1.03,5.4 \pm 1.68,3.02 \pm 0.58$, and $1.66 \pm 0.17 \mathrm{mg} \cdot \mathrm{L}^{-1}$, respectively.

\subsection{DIC and $\delta^{13} C_{D I C}$}

DIC concentrations were relative high at $\mathrm{NN}$ and $\mathrm{DH}$, ranging from 60.91-68.4 and 62.9-66.96 $\mathrm{mg} \mathrm{C} \cdot \mathrm{L}^{-1}$, with averages of $66.52 \pm 1.97$ and $65.8 \pm 0.92 \mathrm{mg} \mathrm{C} \cdot \mathrm{L}^{-1}$, respectively. Narrow ranges of 52.3-56.54 and 25.31-28.84 $\mathrm{mg} \mathrm{C} \cdot \mathrm{L}^{-1}$ with averages of $55.69 \pm 0.73$ and $26.96 \pm 1.01 \mathrm{mg} \mathrm{C} \cdot \mathrm{L}^{-1}$ were observed at $\mathrm{ZZ}$ and DJ. The $\delta^{13} \mathrm{C}_{\text {DIC }}$ averaged $-9.84 \% \pm 0.05 \%,-10.83 \% \pm 0.19 \%,-10.35 \% \pm 0.13 \%$, and $-11.30 \% \pm 0.21 \%$ at $\mathrm{ZZ}, \mathrm{NN}, \mathrm{DJ}$, and $\mathrm{DH}$, and they correspondingly ranged from $-9.97 \%$ o to $-9.73 \%$, $-11.05 \%$ to $-10.45 \%$, $-10.49 \%$ to $-10.17 \%$, and $-11.56 \%$ to $-10.93 \%$, respectively.

\section{Discussion}

\subsection{Characteristics of Groundwater Chemistry and Water-Rock Reactions}

The molar ratio of $\mathrm{Mg}^{2+} / \mathrm{Ca}^{2+}$ is a good indictor to reflect the lithology of aquifers that groundwater flows through $[4,9]$. When this value is much higher than 0.85 , it indicates the dominant presence of dolomite sources. If this ratio was between 0.01 and 0.26 , hydrochemical components in groundwater were mainly derived from limestone sources [9]. In this study, the averaged $\mathrm{Mg}^{2+} / \mathrm{Ca}^{2+}$ ratio was 0.71 , much higher than 0.26 but lower than 0.85 for $\mathrm{ZZ}, \mathrm{NN}$, and $\mathrm{DH}$, indicating that the hydrochemical components were mainly from the dissolution of both dolomite and limestone (Figure 3a). This ratio was much lower than 0.26 at DJ, with an average of 0.12 , suggesting a limestone source at this sampling site. In addition, the molar ratios of $\mathrm{Mg}^{2+} / \mathrm{Ca}^{2+}$ at $\mathrm{ZZ}, \mathrm{NN}$, and $\mathrm{DH}$ varied in a narrow range, from 0.6-0.8. Whereas $\mathrm{SO}_{4}{ }^{2-}$ varied in a large range, the molar ratio at $\mathrm{DJ}$ was much lower (Figure $3 \mathrm{~b}$ ). The result indicated that gypsum should not be considered as the main source of $\mathrm{SO}_{4}{ }^{2-}$ and $\mathrm{Ca}^{2+}$. $\mathrm{SO}_{4}{ }^{2-}$ in groundwater can be sourced from oxidation of sulfide minerals, which are widely distributed in coal-containing strata [11]. In addition, acid rain events often occur in Guiyang, characterized by a high $\mathrm{H}_{2} \mathrm{SO}_{4}$ content, and this is probably also an important source of $\mathrm{SO}_{4}{ }^{2-}$ [19].

The $\mathrm{Ca}^{2+}$ and $\mathrm{Mg}^{2+}$ concentrations were much higher at $\mathrm{DH}$ than those found in other sites, because of the employment of exogenous acid increasing carbonate dissolution in summer. Moreover, domestic sewage discharge, sulfuric acid rain, etc., resulted in increased $\mathrm{H}^{+}$and accelerated carbonate weathering $[20,21]$. As elucidated in Figure $3 \mathrm{c},\left(\mathrm{Mg}^{2+}+\mathrm{Ca}^{2+}\right) /\left(\mathrm{HCO}_{3}{ }^{-}+\mathrm{SO}_{4}{ }^{2-}\right)$ was basically around 1, implying that dissolution of carbonate and S-containing minerals co-affected the hydrochemical compositions of groundwater in Guiyang. It is in agreement with previous studies in Southwestern China [22,23]. This ratio occasionally (from 17-28 August) slightly exceeded 1 at DH, which means that this system needed other anions to balance the excess $\mathrm{Ca}^{2+}$ and $\mathrm{Mg}^{2+}$, especially since this ratio rose to 1.14 at 23rd and 24th of August. Another possible reason for balance would be high nitrate from nitrification [21] due to high human activities [8] in studied sites. Major cations and anions have relative low concentrations in this study when compared to data at these fours sits at the dry season [5], which suggested dilution processes play an important role in water chemistry at karst ground water. 

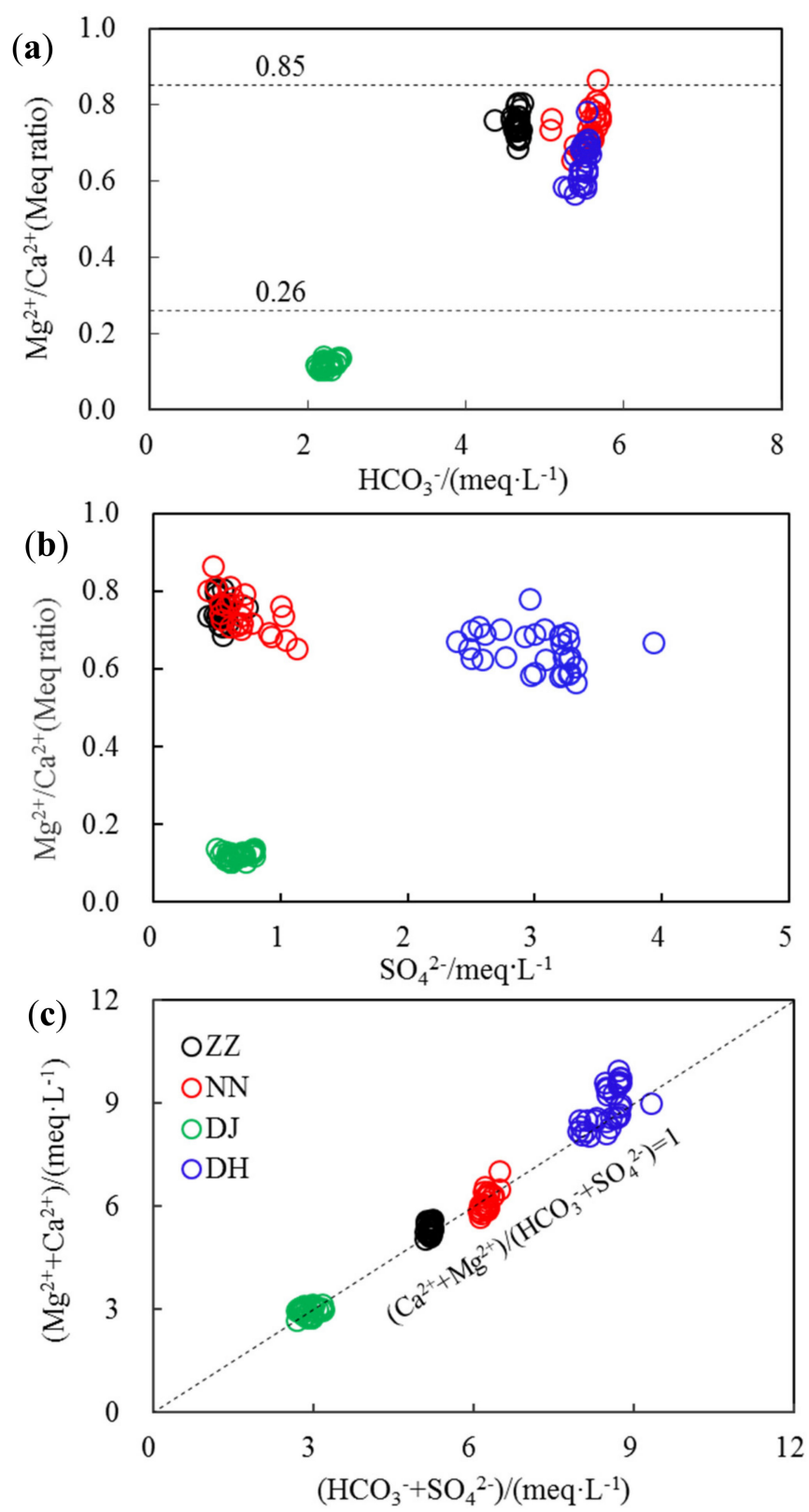

Figure 3. Explanation for regular pattern of hydrochemical composition in groundwater of Guiyang (a) - denotes the ionic source of different lithology as calcite or dolomite; (b) - denotes the gypsum contribution to ionic composition; (c)—denotes the balance of main cations and main anions; meq. $\mathrm{L}^{-1}$ denotes the unit of ionic level by milliequivalent per liter; Meq Ratio denotes the ratios of ionic contents by milliequivalent units.

Both $\mathrm{H}_{2} \mathrm{CO}_{3}$ and $\mathrm{H}_{2} \mathrm{SO}_{4}$ can play a part in minerals' dissolution according to reaction formula (Equation (2)) [22,24]. Figure 4 shows the variations of $\left(\mathrm{Ca}^{2+}+\mathrm{Mg}^{2+}\right) / \mathrm{HCO}_{3}^{-}$vs. $\mathrm{SO}_{4}{ }^{2-} / \mathrm{HCO}_{3}{ }^{-}$ equivalent ratios for the water samples. The transformation mechanism for them was interpreted as follows:

$$
\mathrm{Ca}_{\mathrm{x}} \mathrm{Mg}_{1-\mathrm{x}} \mathrm{CO}_{3}+\mathrm{H}_{2} \mathrm{SO}_{4}+\mathrm{H}_{2} \mathrm{CO}_{3}=3 \times \mathrm{Ca}^{2+}+3(1-\mathrm{x}) \mathrm{Mg}^{2+}+\mathrm{SO}_{4}^{2-}+4 \mathrm{HCO}_{3}^{-}
$$




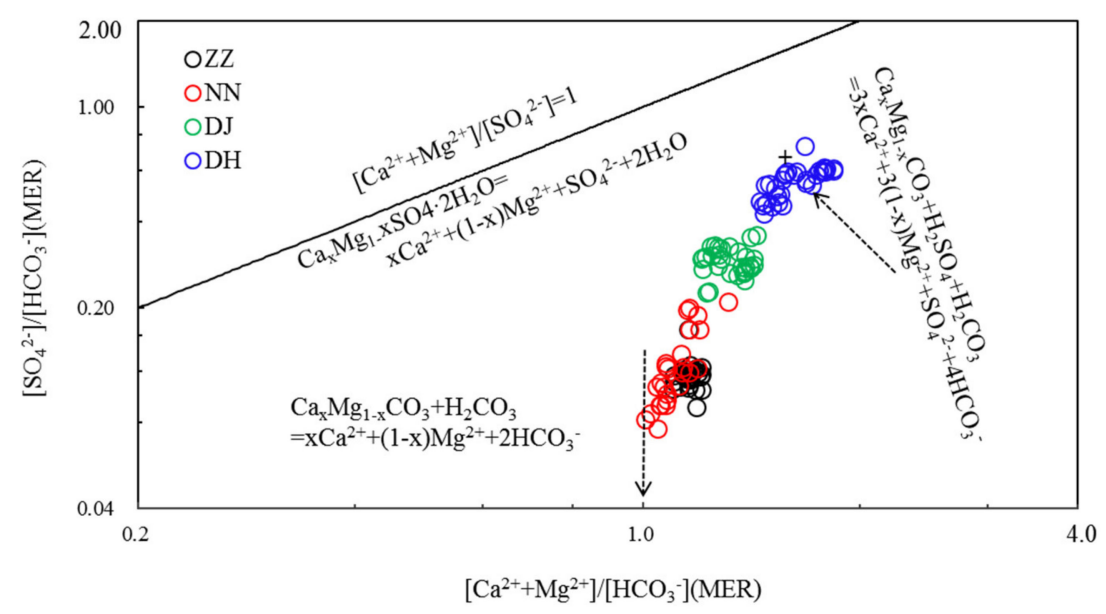

Figure 4. Variations of $\mathrm{SO}_{4}{ }^{2-} / \mathrm{HCO}_{3}{ }^{-}$with $\left(\mathrm{Ca}^{2+}+\mathrm{Mg}^{2+}\right) / \mathrm{HCO}_{3}{ }^{-}$equivalent ratios in the groundwater of Guiyang (MER-milliequivalent ratio).

The chemical reactions would be most likely responsible for the water chemistry. For water samples with unified $\left(\mathrm{Ca}^{2+}+\mathrm{Mg}^{2+}\right) / \mathrm{HCO}_{3}{ }^{-}$and low $\mathrm{SO}_{4}{ }^{2-} / \mathrm{HCO}_{3}{ }^{-}$ratios, carbonate dissolution by $\mathrm{H}_{2} \mathrm{CO}_{3}$ dominated the mineral/water interaction. With the increasing $\mathrm{SO}_{4}{ }^{2-} / \mathrm{HCO}_{3}{ }^{-}$ratios, the $\left(\mathrm{Ca}^{2+}+\right.$ $\left.\mathrm{Mg}^{2+}\right) / \mathrm{HCO}_{3}{ }^{-}$ratio also increased, and more $\mathrm{SO}_{4}{ }^{2-}$ was needed to balance the excess $\mathrm{Ca}^{2+}$ and $\mathrm{Mg}^{2+}$ in the water samples.

When carbonate dissolution by both $\mathrm{H}_{2} \mathrm{CO}_{3}$ and $\mathrm{H}_{2} \mathrm{SO}_{4}$, water should have a $\mathrm{SO}_{4}{ }^{2-} / \mathrm{HCO}_{3}{ }^{-}$ratio of 0.5 and a $\left(\mathrm{Ca}^{2+}+\mathrm{Mg}^{2+}\right) / \mathrm{HCO}_{3}{ }^{-}$ratio of 1.5 , as shown by Figure 4 . When both $\mathrm{SO}_{4}{ }^{2-} / \mathrm{HCO}_{3}{ }^{-}$and $\left(\mathrm{Ca}^{2+}+\mathrm{Mg}^{2+}\right) / \mathrm{HCO}_{3}{ }^{-}$ratios continued to increase, dissolution of gypsum was needed to balance the negative and positive ions. The covariation of $\left(\mathrm{Ca}^{2+}+\mathrm{Mg}^{2+}\right) / \mathrm{HCO}_{3}{ }^{-}$and $\mathrm{SO}_{4}{ }^{2-} / \mathrm{HCO}_{3}{ }^{-}$ratios can also be interpreted as binary mixing of $\mathrm{HCO}_{3}{ }^{-}$type and $\mathrm{SO}_{4}{ }^{2-}$ type water, revealing that water chemistry originated mainly from carbonate dissolution by $\mathrm{H}_{2} \mathrm{CO}_{3}$ and $\mathrm{H}_{2} \mathrm{SO}_{4}$.

The proportion of elements can be used to investigate the water-rock interaction and the chemical evolution of groundwater [9]. Generally, studying on the affinity of water chemistry throws light on the geochemical characteristics of the aquifer. The incorporation of industrial and urban $\mathrm{NaCl}$ and potash fertilizers, manure and $\mathrm{N}$-containing fertilizers used in agricultural production into aquifers will lead to the increase of $\mathrm{K}^{+}$and $\mathrm{Na}^{+}$in groundwater. As shown in Figure 5, the sewage samples at $\mathrm{DH}$ showed low $\mathrm{K}^{+} / \mathrm{Na}^{+}$ratios, meaning that sewage was strongly enriched in $\mathrm{Na}^{+}$. The relationship between $\mathrm{Na}^{+} / \mathrm{HCO}_{3}{ }^{-}$and $\mathrm{K}^{+} / \mathrm{HCO}_{3}{ }^{-}$at $\mathrm{ZZ}$ and $\mathrm{NN}$ indicated that groundwater has received significant agricultural input. The correlation between $\mathrm{Na}^{+} / \mathrm{HCO}_{3}{ }^{-}$and $\mathrm{K}^{+} / \mathrm{HCO}_{3}{ }^{-}$was not observed at DJ and $\mathrm{DH}$, and the characteristic of the hydrochemical components will be explained below. 


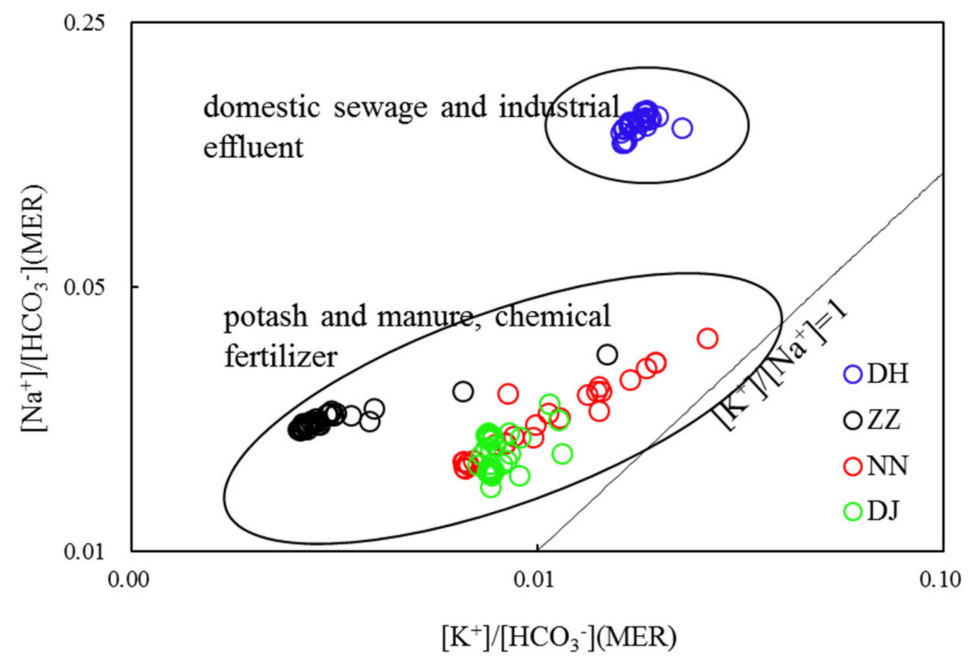

Figure 5. Correlations of $\mathrm{HCO}_{3}{ }^{-}$normalized by the $\mathrm{Na}^{+}$and $\mathrm{K}^{+}$values (molar ratios) of groundwaters in Guiyang (MER-milliequivalent ratio).

\subsection{Response of Groundwater to Rainfall Events and Evolution of Water Quality}

$\mathrm{Cl}^{-}$is conservative, showing an increasing trend from the upper reaches of the Nanming River due to anthropogenic inputs [11]. Halite and marine sources were not the main sources of $\mathrm{Cl}^{-}$, but from agricultural fertilizers, domestic sewage, animal manure, and $\mathrm{Cl}_{2}$ disinfection treatment of tap water [25]. Figure 6 shows the temporal variations of major ions during the sampling period. The ions, which were the result of anthropogenic inputs, included $\mathrm{NO}_{3}{ }^{-}, \mathrm{Cl}^{-}, \mathrm{Na}^{+}, \mathrm{K}^{+}$, and performed consistently with that of $\mathrm{SO}_{4}{ }^{2-}$ at $\mathrm{ZZ}, \mathrm{NN}$, and $\mathrm{DH}\left(\mathrm{R}^{2}=0.75, p \leqq 0.01\right)$, with an exception at DJ, which was covered with a large area of vegetation (Figure 6). Once the concentration of $\mathrm{SO}_{4}{ }^{2-}$ exceeds $100 \mathrm{mg} \cdot \mathrm{L}^{-1}$ (average level $144.8 \mathrm{mg} \cdot \mathrm{L}^{-1}$ ), this means that the anthropogenic input of $\mathrm{SO}_{4}{ }^{2-}$ is from the sewage effluent rather than the natural sources at $\mathrm{DH} . \mathrm{SO}_{4}{ }^{2-}$ at $\mathrm{ZZ}, \mathrm{NN}$, and $\mathrm{DH}$ exhibited obvious anticorrelations with $\mathrm{HCO}_{3}{ }^{-}\left(\mathrm{R}^{2}=0.72, p \leqq 0.01\right)$, which implied that $\mathrm{H}_{2} \mathrm{SO}_{4}$ played an important role in DIC production, mediating in mineral weathering such as the oxidation of S-containing coal strata or organic matter in sewage effluent [26]. Contrarily, $\mathrm{SO}_{4}{ }^{2-}$ at $\mathrm{DJ}$ varied correspondingly to $\mathrm{HCO}_{3}{ }^{-}\left(\mathrm{R}^{2}=0.43, p \leqq 0.01\right)$, due to the carbonate dissolution by $\mathrm{H}_{2} \mathrm{SO}_{4}$ and $\mathrm{H}_{2} \mathrm{CO}_{3}$ in the region with less anthropogenic input that led to $\mathrm{SO}_{4}{ }^{2-}$ and $\mathrm{HCO}_{3}{ }^{-}$production of similar variation trends (Figure 6). This viewpoint further confirmed the finding that $\mathrm{SO}_{4}{ }^{2-}$ originated from the decomposition of manure, fertilizer, and municipal sewage in groundwater samples at $\mathrm{ZZ}, \mathrm{NN}$, and DH. DJ is situated in woodland and has not been influenced by industrial and residential effluent. However, it is an exception at $\mathrm{DJ}$, in that $\mathrm{HCO}_{3}{ }^{-}$and $\mathrm{SO}_{4}{ }^{2-}$ exhibited a consistent trend and without any correlations to other ions, demonstrating that $\mathrm{SO}_{4}{ }^{2-}$ had a significant natural source from mineral weathering according to reaction formula (Equation (2)). 


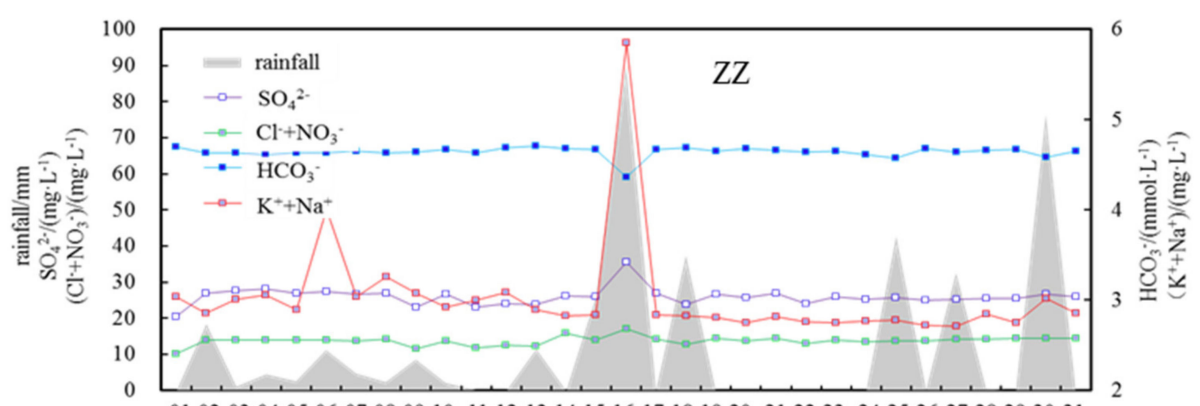

01020304050607080910111213141516171819202122232425262728293031

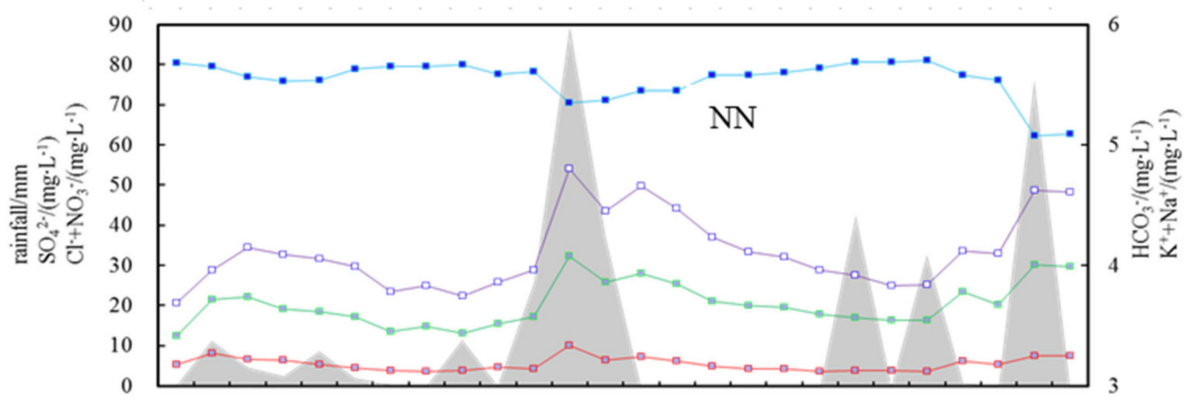

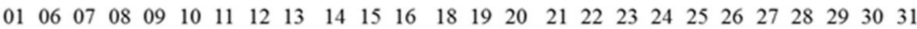

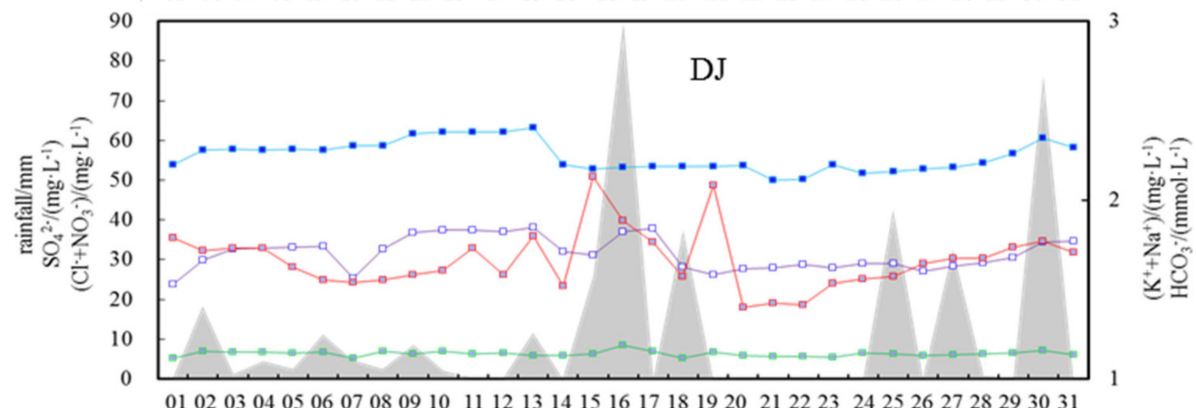

0102030405060708091011121314151617181920212223242526272829303 ।

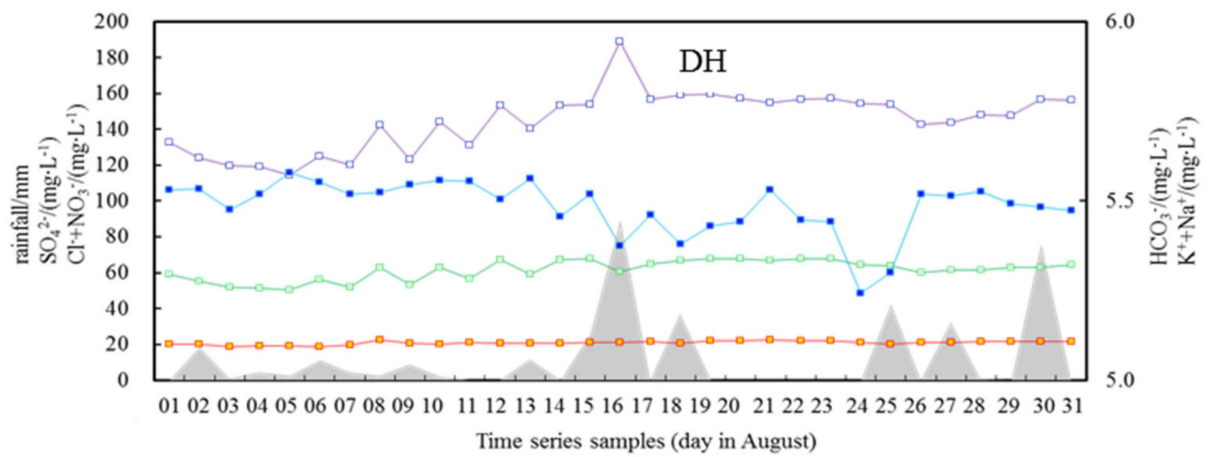

Figure 6. The temporal variations of major ions of different groundwater sampling sites and rainfall along sampling days at Guiyang.

Atmospheric precipitation is the main source of regional groundwater, and surface water is hydraulically closely linked to groundwater [25]. It has been reported that the average concentrations of major ions in summer were generally lower than other seasons in Guiyang groundwater, due to the influx of infiltrated rain with low solutes contents [11]. As illustrated in Figure 6, rainfall influenced the ionic compositions in that $\mathrm{HCO}_{3}{ }^{-}$decreased abruptly with the heavy rain at 16th, August. Obviously, $\mathrm{HCO}_{3}{ }^{-}$from natural sources was acutely diluted by the heavy rainfall due to the large rain exchange flux, and impacted by the removal of the total quantity from weathered rocks [5]. However, frequent rainfall did not change ion concentration largely in the following days due to adaption of water-rock reaction in high rainfall periods. Whereas $\mathrm{SO}_{4}{ }^{2-}, \mathrm{K}^{+}, \mathrm{Na}^{+}$, and $\mathrm{NO}_{3}{ }^{-}$increased quickly under heavy rain, similar to the findings of other study [27] that this group of ions were from 
anthropogenic discharge, washed and infiltrated into river water and elevated significantly during rainfall events. Although $\mathrm{SO}_{4}{ }^{2-}$ at DJ originated similarly from mineral dissolution, which was not as susceptible to being affected by heavy rain as $\mathrm{HCO}_{3}{ }^{-}$, it is probably due to occasional manure and fertilizer decomposition, or else a contribution from acid rain.

The relationship between ions and meteoric water could be used to constrain the sources of contaminants and their conversions. The hydrogeological features of karst areas permit the rapid penetration of pollutants into groundwater, so karst ground waters are more vulnerable to being polluted from human activities than other types of aquifers [25]. Groundwater in karst areas has been increasingly polluted by penetration of pollutants, e.g., uncontrolled urban sewage effluent and intensive utilization of fertilizers on cultivated land [15,25]. For $\mathrm{HCO}_{3}{ }^{-}, \mathrm{Ca}^{2+}$, and $\mathrm{Mg}^{2+}$, there is a relative low ion content in rainwater compared with that in groundwater [19]. The infiltrated meteoric water diluted and eroded the concentrations of $\mathrm{HCO}_{3}{ }^{-}, \mathrm{Ca}^{2+}$, and $\mathrm{Mg}^{2+}$, but $\mathrm{NO}_{3}{ }^{-}, \mathrm{SO}_{4}{ }^{2-}, \mathrm{K}^{+}$, and $\mathrm{Na}^{+}$ were eluted out and leached into groundwater mainly due to anthropogenic input from agricultural fertilizer, industrial waste, and domestic sewage following the rainfall [21]. Thus, relative high flow during the rainfall periods can lead to rapid leaching of surficial fertilizers/manure into the groundwater system through conduits due to weak buffering capacity in the studied area. Of course, the different response to rainfall in various groundwater sites suggested different role of high heterogeneity of karst system and extent of human activities as well as multi biogeochemical processes.

\subsection{DIC Sources and the Controlling Factors in Groundwater}

In the groundwater, the sources of DIC are from (1) the dissolution and dissociation of $\mathrm{CO}_{2}(\mathrm{~g})$, mainly from root respiration and soil organic matter decay, which is infiltrated in subsurface water systems, and (2) the dissolution of carbonates by organic acids excreted by plant roots, and carbonic acid produced by the dissolution of the $\mathrm{CO}_{2}$ in water $[13,28,29]$. The dissolution of carbonates (calcite and dolomite) is a major source of $\mathrm{Ca}^{2+}$ and $\mathrm{Mg}^{2+}$, which also generate DIC in groundwater. These are expressed as the following reactions (Equation (3)) and (Equation (4)).

$$
\begin{gathered}
\mathrm{CaCO}_{3}+\mathrm{H}_{2} \mathrm{O}+\mathrm{CO}_{2}(\mathrm{~g}) \leftrightarrow \mathrm{Ca}^{2+}+\mathrm{HCO}_{3}^{-} \\
\mathrm{CaMg}\left(\mathrm{CO}_{3}\right)_{2}+2 \mathrm{H}_{2} \mathrm{O}+2 \mathrm{CO}_{2} \leftrightarrow \mathrm{Ca}^{2+}+\mathrm{Mg}^{2+}+4 \mathrm{HCO}_{3}^{-}
\end{gathered}
$$

The DIC sources are also likely to be organic residuals that are degraded by microbes, which will generate DIC to the water $[18,26]$. A large of aerobic and anaerobic populations predominates the downgradient from the pit water contaminated source [26]. As $\mathrm{CO}_{2}(\mathrm{~g})$ is generated by the microbiological degradation of hydrocarbons, which added to the $\mathrm{CO}_{2}(\mathrm{~g})$ generated from the organic matter respiration in the root zone, then the soil $\mathrm{CO}_{2}$ dissolves carbonates to produce DIC in the aquifer. However, hydrocarbon microbial mineralization should not be an important source of DIC [16]. Guiyang suffered from acid rain, which contains high sulfate [19]. Since sulfide minerals oxidation in the coal-containing strata [9], sulfuric acid plays a significant role in dissolving the carbonate rocks in this study area, producing DIC in groundwater.

Soil $\mathrm{CO}_{2}(\mathrm{~g})$, from respiration of $\mathrm{C}-3$ plant, dissolving in groundwater produces DIC, with a $\delta^{13} \mathrm{C}_{\text {DIC }}$ value of $-23 \%$ o $[4,30]$. It is reported that Triassic and Permian limestone and dolomite are the most widely distributed strata in the studied area, with $\delta^{13} \mathrm{C}$ values ranging from $-1.8-4.8 \%$ [31]. Supposing that $\delta^{13} \mathrm{C}$ only originated from soil $\mathrm{CO}_{2}$ influx and carbonate rock weathering, the $\delta^{13} \mathrm{C}$ value should be $-11 \%[4,23] . \delta^{13} \mathrm{C}$ values were much higher than $-11 \%$ at $\mathrm{ZZ}, \mathrm{NN}$, and DJ, whereas it fluctuated around $-11 \%$ or even lower at $\mathrm{DH}$. The $\delta^{13} \mathrm{C}$ values for all samples were lower than $-9 \%$, suggesting the contribution of soil $\mathrm{CO}_{2}$ influx. DIC generally has more negative $\delta^{13} \mathrm{C}$ value comparing to the data in the dry season from previous study [5], indicating DIC in the wet season has a relatively enriched biogenic origin relative to the dry season.

In this study, $\mathrm{HCO}_{3}^{-}$is more than $95 \%$ of DIC based on water chemistry and $\mathrm{pH}$. Milliequivalent ratios (MER) of $\left(\mathrm{Ca}^{2+}+\mathrm{Mg}^{2+}\right) / \mathrm{HCO}_{3}{ }^{-}$of the groundwater in Guiyang were in the range 
of 1-2, averaging 1.16, 1.11, 1.32, and 1.63 at $\mathrm{ZZ}, \mathrm{NN}, \mathrm{DJ}$, and $\mathrm{DH}$, respectively. The $\mathrm{SO}_{4}{ }^{2-} / \mathrm{HCO}_{3}{ }^{-}$ ratios averaged $0.12,0.13,0.29$, and 0.55 at $\mathrm{ZZ}, \mathrm{NN}, \mathrm{DJ}$, and $\mathrm{DH}$, respectively. The relationship between $\left(\mathrm{Ca}^{2+}+\mathrm{Mg}^{2+}\right) / \mathrm{HCO}_{3}{ }^{-}$and $\mathrm{SO}_{4}{ }^{2-} / \mathrm{HCO}_{3}{ }^{-}$indicated that $\mathrm{H}_{2} \mathrm{SO}_{4}$ acted a role in the mineral weathering. In addition, $\mathrm{HCO}_{3}{ }^{-}$normalized $\mathrm{SO}_{4}{ }^{2-}$ value decreased in the rank of $\mathrm{DH}>\mathrm{DJ}>\mathrm{NN}>\mathrm{ZZ}$, suggesting that $\mathrm{H}_{2} \mathrm{SO}_{4}$ was decreasingly involved in carbonate weathering, as elucidated in Figure 4 [6]. Samples at $\mathrm{DH}$ showed a relatively high $\mathrm{SO}_{4}{ }^{2-} / \mathrm{HCO}_{3}{ }^{-}$ratio and the lowest $\delta^{13} \mathrm{C}$ value (Figure 7). These results corresponded to the discussion of previous study [11], showing that since $\mathrm{SO}_{4}{ }^{2-}$ was mainly derived from oxidation of sulfide minerals or mineralization of organic sulfur. In this study, groundwater would be characterized by a high $\mathrm{SO}_{4}{ }^{2-} / \mathrm{HCO}_{3}{ }^{-}$ratio, but $\delta^{13} \mathrm{C}$-depleted DIC value. The carbonate evolution with the average $\delta^{13} \mathrm{C}_{\mathrm{DIC}}$ of $-11.3 \%$ at $\mathrm{DH}$ was undergoing in a closed system from carbonate weathering by soil $\mathrm{CO}_{2}(\mathrm{~g})$ [16]. The $\delta^{13} \mathrm{C}$ of $-9.8 \%$ at $\mathrm{ZZ}$ was similar to the $\delta^{13} \mathrm{C}$ of $-9.4 \%$ in $\mathrm{SO}_{4}{ }^{2-}$-rich water, both due to dedolomitization referred to previous study [16], that high $\delta^{13} \mathrm{C}$ values were relative to the result of the other sampling sites. $\left[\mathrm{NO}_{3}{ }^{-}\right] /\left[\mathrm{HCO}_{3}{ }^{-}\right]$averaged $0.03,0.05$, 0.03 , and 0.1 , likewise, displayed the same variation trend with $\left(\mathrm{Ca}^{2+}+\mathrm{Mg}^{2+}\right) / \mathrm{HCO}_{3}{ }^{-}$at $\mathrm{NN}$ and $\mathrm{DH}$, resulting in the lower $\delta^{13} \mathrm{C}$ values at $\mathrm{NN}$ and $\mathrm{DH}$ (Figure 7). It was inferred that carbonate weathering could be driven by nitric acid. However, $\mathrm{NO}_{3}{ }^{-}$might play a minor role in shifting $\delta^{13} \mathrm{C}$-depleted values due to oxidization of organic matter in sewage effluent at site of DH.

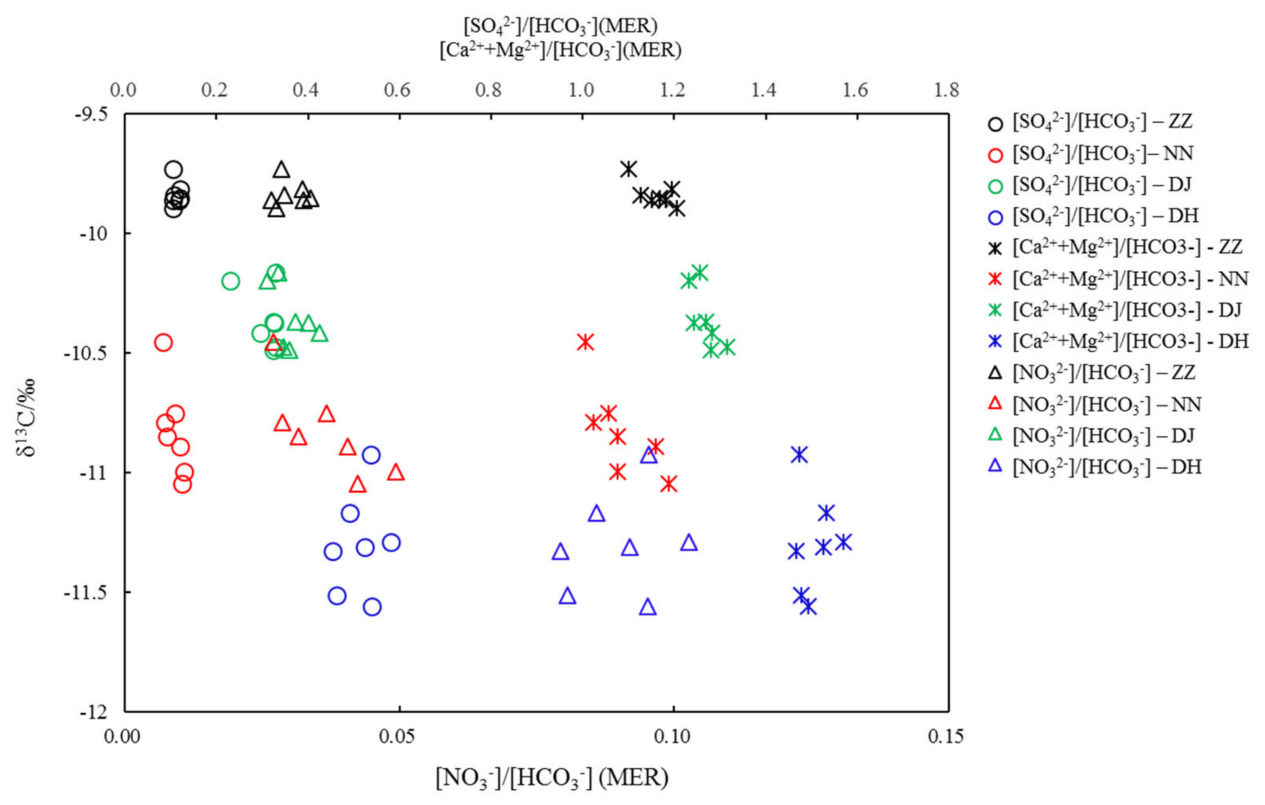

Figure 7. Covariations between $\delta^{13} \mathrm{C}_{\mathrm{DIC}}$ and concentrations of $\mathrm{SO}_{4}{ }^{2-},\left(\mathrm{Ca}^{2+}+\mathrm{Mg}^{2+}\right)$, and $\mathrm{NO}_{3}{ }^{-}$ normalized by $\mathrm{HCO}_{3}^{-}$(MER: milliequivalent ratio).

As shown in Figure 7, $\mathrm{NO}_{3}{ }^{-}$played an important role in $\mathrm{HCO}_{3}{ }^{-}$dynamics only at $\mathrm{NN}$, reflecting on the anticorrelation between them $\left(R^{2}=0.72, p \leqq 0.01\right)$. It was postulated that the transformation from organic carbon to DIC occurred with $\mathrm{NO}_{3}{ }^{-}$-mediating in the redox reactions, shifting negative $\delta^{13} C_{\text {DIC }}$ values. Probably this could be taken as a plausible explanation for the lower $\delta^{13} \mathrm{C}$ value at $\mathrm{NN}$ than that at DJ. Utilization of manure and nitrogenous fertilizer produces $\mathrm{H}^{+}$during their oxidation, and sulfides in coal seams are oxidized into sulfuric acid, both of which promote the weathering of carbonate rocks and result in high $\mathrm{NO}_{3}{ }^{-}$and $\mathrm{SO}_{4}{ }^{2-}$ concentrations and $\delta^{13} \mathrm{C}$-enriched DIC values in karst waters [21,23,25]; therefore, nitric acid and sulfuric acid were also the driving factors for mineral dissolution and heavy $\delta^{13} \mathrm{C}$. In addition, mineral dissolution and organic matter decomposition caused the $\delta^{13} \mathrm{C}$ values to fluctuate $[17,32] ; \delta^{13} \mathrm{C}$ values deviated off $-11 \%$ toward a more positive value, significantly negatively correlated to $\mathrm{NO}_{3}{ }^{-} / \mathrm{HCO}_{3}{ }^{-}$and $\mathrm{SO}_{4}{ }^{2-} / \mathrm{HCO}_{3}{ }^{-}$ratios at $\mathrm{NN}\left(\mathrm{R}^{2}=0.61, p \leqq 0.01\right)$, explained by the above elaboration that carbonate dissolution was significantly shifted by $\mathrm{H}_{2} \mathrm{CO}_{3}, \mathrm{H}_{2} \mathrm{SO}_{4}$, and $\mathrm{HNO}_{3}$, along with organic matter being oxidized into DIC by $\mathrm{SO}_{4}{ }^{2-}$ 
and $\mathrm{NO}_{3}{ }^{-}$. This phenomenon was not observed at $\mathrm{ZZ}, \mathrm{DJ}$, and $\mathrm{DH}$, which further demonstrated that carbonate weathering by $\mathrm{SO}_{4}{ }^{2-}$ and $\mathrm{NO}_{3}{ }^{-}$and organic carbon transformation were not the only factors influencing the $\delta^{13} \mathrm{C}_{\text {DIC }}$. The $\delta^{13} \mathrm{C}_{\text {DIC }}$ value of groundwater in Guiyang is mainly influenced by anthropogenic inputs following by carbonate rock weathering and soil $\mathrm{CO}_{2}(\mathrm{~g})$ influx. $\delta^{13} \mathrm{C}_{\mathrm{DIC}}$ decreased with the increasing quotients of $\mathrm{SO}_{4}{ }^{2-}$ and $\mathrm{NO}_{3}{ }^{-}$vs. $\mathrm{HCO}_{3}{ }^{-}$at these sampling sites, indicating that $\mathrm{H}_{2} \mathrm{SO}_{4}$ and $\mathrm{HNO}_{3}$ were not only involved in carbonate mineral dissolution, but also in organic matter oxidation. In addition, soil $\mathrm{CO}_{2}(\mathrm{~g})$ influx shift DIC with $\delta^{13} \mathrm{C}$-depleted values.

\section{Conclusions}

This study investigated temporal and spatial variations of water chemistry at the rainy season in a typical karst groundwater system, SW China. Groundwater had a high content of $\mathrm{Ca}^{2+}, \mathrm{Mg}^{2+}$, $\mathrm{HCO}_{3}{ }^{-}$, and $\mathrm{SO}_{4}{ }^{2-}$ in the study region, which accounted for more than $90 \%$ of total ions and were largely derived from dissolution of carbonate rocks. The chemical composition of ground water was mainly controlled by rock dissolution. Anthropogenic inputs into the groundwater mainly include $\mathrm{SO}_{4}{ }^{2-}, \mathrm{Cl}^{-}$, and $\mathrm{NO}_{3}{ }^{-}$, according to the chemical composition of municipal sewage in Guiyang. Domestic and industrial waste was the main contaminant sources of groundwater in urban areas, while agricultural fertilizers and the transformation products polluted groundwater in suburbs.

The study showed that carbonate evolution in freshwater aquifers could be traced by investigating the major ions and $\delta^{13} \mathrm{C}_{\mathrm{DIC}}$. The coupled analysis of $\delta^{13} \mathrm{C}_{\mathrm{DIC}}$ and hydrochemical parameters is an effective approach to explore the biogeochemical processes of carbon and trace the sources of groundwater pollutants in karst areas. Groundwater sampled from the city center (DH) showed the highest ionic level and lowest $\delta^{13} \mathrm{C}$ values relative to the other samples due to undergoing different carbonate evolution.

Supplementary Materials: The following are available online at http:/www.mdpi.com/1660-4601/17/7/2520/s1, Table S1: The major ions concentration in groundwater samples at Guiyang.

Author Contributions: Experimental design, M.X. and Z.W.; methodology, M.X. and Z.H.; validation, S.X. and Z.W.; formal analysis, M.X.; investigation, M.X. and S.X.; data curation, Z.H.; writing-original draft preparation, M.X.; writing-review and editing, Z.W.; supervision, M.X. and Z.W.; project administration, M.X.; funding acquisition, M.X. All authors have read and agreed to the published version of the manuscript.

Funding: This research was funded by National Natural Science Foundation China (41373138) and Talent Introduction Project (5KGCC18002) from Tianjin Normal University, China.

Acknowledgments: We thank Eileen Richardson from University of Glasgow for polishing the English of this manuscript.

Conflicts of Interest: The authors declare no conflict of interest.

\section{References}

1. Hartmann, A.; Goldscheider, N.; Wagener, T.; Lange, J.; Weiler, M. Karst water resources in a changing world: Review of hydrological modeling approaches. Rev. Geophys. 2014, 52, 218-242. [CrossRef]

2. Ford, D.; Williams, P.D. Karst Hydrogeology and Geomorphology; John Wiley \& Sons: Hoboken, NJ, USA, 2013.

3. Hanshaw, B.B.; Back, W. Major geochemical processes in the evolution of carbonate-aquifer systems. J. Hydrol. 1979, 43, 287-312. [CrossRef]

4. Clark, I.D.; Fritz, P. Environmental Isotopes in Hydrogeology; CRC Press: Boca Raton, FL, USA, 1997.

5. Li, S.L.; Liu, C.Q.; Tao, F.X.; Lang, Y.C.; Han, G.L. Carbon biogeochemistry of ground water, Guiyang, southwest China. Ground Water 2005, 43, 494-499. [CrossRef] [PubMed]

6. Jiang, Y. The contribution of human activities to dissolved inorganic carbon fluxes in a karst underground river system: Evidence from major elements and $\delta^{13} \mathrm{C}_{\text {DIC }}$ in Nandong, Southwest China. J. Contam. Hydrol. 2013, 152, 1-11. [CrossRef] [PubMed]

7. Cane, G.; Clark, I.D. Tracing groundwater recharge in an agricultural watershed with isotopes. Groundwater 1998, 37, 133-139. [CrossRef] 
8. Liu, C.Q.; Li, S.L.; Lang, Y.C.; Xiao, H.Y. Using $\delta^{15} \mathrm{~N}$ - and $\delta^{18} \mathrm{O}$-values to identify nitrate sources in karst groundwater, Guiyang, southwest China. Environ. Sci. Technol. 2006, 40, 6928-6933. [CrossRef]

9. Liu, C.Q. Biogeochemical Processes and Cycling of Nutrients in the Earth's Surface: Chemical Erosion and Nutrient Cycling in Karstic Catchments, Southwest China; Science Press: Beijing, China, 2007. (In Chinese)

10. Zhong, J.; Li, S.L.; Cai, H.M.; Yue, F.J.; Tao, F.X. The response of carbon geochemistry to hydrological events within an urban river, Southwestern China. Geochem. Int. 2018, 56, 462-473. [CrossRef]

11. Lang, Y.C.; Liu, C.Q.; Zhao, Z.Q.; Li, S.L.; Han, G.L. Geochemistry of surface and groundwater in Guiyang, China: Water/ rock interaction and pollution in a karst hydrological system. Appl. Geochem. 2006, 21, 887-903. [CrossRef]

12. Yuan, D. Chinese Karst Science; Geological Publishing House: Beijing, China, 1993. (In Chinese)

13. Appelo, C.A.J.; Postma, D. Geochemistry, Groundwater and Pollution; CRC: Boca Raton, FL, USA, 2005.

14. Alley, W.A.; Healy, R.W.; LaBaugh, J.W.; Reilly, T.E. Flow and storage in groundwater systems. Science 2002, 296, 1985-1990. [CrossRef]

15. Jordana, S.; Batista, E. Natural groundwater quality and health. Geol. Acta 2004, 2, 175-188.

16. Atekwana, E.A.; Seeger, E.J. Carbonate and carbon isotopic evolution of groundwater contaminated by produced water brine with hydrocarbons. Appl. Geochem. 2015, 63, 105-115. [CrossRef]

17. Zhong, J.; Li, S.L.; Tao, F.; Yue, F.; Liu, C.Q. Sensitivity of chemical weathering and dissolved carbon dynamics to hydrological conditions in a typical karst river. Sci. Rep. 2017, 7, 42944. [CrossRef] [PubMed]

18. Zhong, J.; Li, S.L.; Liu, J.; Ding, H.; Sun, X.L.; Xu, S. Climate variability controls on $\mathrm{CO}_{2}$ consumption fluxes and carbon dynamics for monsoonal rivers: Evidence from Xijiang River, Southwest China. J. Geophys. Res. Biogeosci. 2018, 123, 2553-2567. [CrossRef]

19. Han, G.L.; Liu, C.-Q. Strontium isotope and major ion chemistry of the rainwaters from Guiyang, Guizhou Province, China. Sci. Total Environ. 2006, 364, 165-174. [CrossRef] [PubMed]

20. Perrin, A.S.; Probst, A.; Probst, J.L. Impact of nitrogenous fertilizers on carbonate dissolution in small agricultural catchments: Implications for weathering $\mathrm{CO}_{2}$ uptake at regional and global scales. Geochim. Cosmochim. Acta 2008, 72, 3105-3123. [CrossRef]

21. Yue, F.; Li, S.; Liu, C.; Lang, Y.; Ding, H. Sources and transport of nitrate constrained by the isotopic technique in a karst catchment: An example from Southwest China. Hydrol. Process. 2015, 29, 1883-1893. [CrossRef]

22. Li, S.L.; Calmels, D.; Han, G.; Gaillardet, J.; Liu, C.Q. Sulfuric acid as an agent of carbonate weathering constrained by 13CDIC: Examples from Southwest China. Earth Planet. Sci. Lett. 2008, 170, 189-199. [CrossRef]

23. Liu, J.; Ding, H.; Xiao, M.; Xu, Z.Y.; Wei, Y.; Su, Z.H.; Zhao, L.; Peng, J.T.; Wang, H.; Wang, X.D. Climatic variabilities control the solute dynamics of monsoon karstic river: Approaches from $\mathrm{C}-\mathrm{Q}$ relationship, isotopes and model analysis in the Liujiang River. Water 2020, 12, 862. [CrossRef]

24. Massmann, G.; Tichomirowa, M.; Merz, C.; Pekdeger, A. Sulfide oxidation and sulfate reduction in a shallow ground water system (Oderbruch Aquifer, Germany). J. Hydrol. 2003, 278, 231-243. [CrossRef]

25. Li, X.D.; Liu, C.Q.; Harue, M.; Li, S.L.; Liu, X.L. The use of environmental isotopic (C, Sr, S) and hydrochemical tracers to characterize anthropogenic effects on karst groundwater quality: A case study of the Shuicheng Basin, SW China. Appl. Geochem. 2010, 25, 1924-1936. [CrossRef]

26. Godsy, E.M.; Hostettler, F.D.; Warren, E.; Paganelli, V.V.; Kharaka, Y.K. Environmental Impacts of Petroleum Production: The Fate of Petroleum and Other Organics Associated with Produced Water from the Osage-Skiatook Petroleum Environmental Research Sites, Osage County, Oklahoma; U.S. Geological Survey Water-Resources Investigations Report; U.S. Geological Survey: Reston, VA, USA, 2003.

27. Wang, Z.J.; Li, S.L.; Yue, F.J.; Qin, C.Q.; Buckerfield, S.; Zeng, J. Rainfall driven nitrate transport in agricultural karst surface river system: Insight from high resolution hydrochemistry and nitrate isotopes. Agric. Ecosyst. Environ. 2020, 291, 106787. [CrossRef]

28. Martin, J.B. Carbonate minerals in the global carbon cycle. Chem. Geol. 2017, 449, 58-72. [CrossRef]

29. Li, X.; Han, G.; Liu, M.; Song, C.; Zhang, Q.; Yang, K.; Liu, J. Hydrochemistry and Dissolved Inorganic Carbon (DIC) cycling in a tropical agricultural river, Mun River Basin, Northeast Thailand. Int. J. Environ. Res. Pub. Health 2019, 16, 3410. [CrossRef] [PubMed]

30. Deirmendjian, L.; Abril, G. Carbon dioxide degassing at the groundwater-stream-atmosphere interface: Isotopic equilibration and hydrological mass balance in a sandy watershed. J. Hydrol. 2018, 558, 129-143. [CrossRef] 
31. Nan, J.; Zhou, D.; Ye, J.; Wang, Z. Geochemical studies on Permian-Triassic paleoclimate and paleo-ocean environment in Guizhou Province, China. Acta Miner. Sin. 1998, 18, 239-249, (In Chinese with English Abstract).

32. Jin, J.; Zimmerman, A.R.; Moore, P.J.; Martin, J.B. Organic and inorganic carbon dynamics in a karst aquifer: Santa Fe River Sink-Rise system, north Florida, USA. J. Geophys. Res. Biogeosci. 2014, 119, 340-357. [CrossRef] 